\section{沼の平の Patterned Grounds}

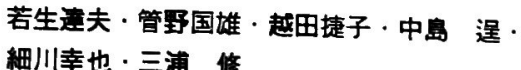

磐梯山 $(1,819 \mathrm{~m})$ - 赤埴山 $(1,427 \mathrm{~m})$ ○間に 位置一る沼刀平 $(1,380 \mathrm{~m})$ は, 湿地 (夏季) と 緩傾斜地（湿地つ東的よひ南に付布し，角砅層 よりなる)とに分けられる。

若汒は，1962年，この地で規則性ある地形を みいだし，更にこれは構造土類似の地形てい 志るが，二つ典型的断面を示さない可能性つあ ることに気がついた。筆者らは，1963 年7月， 現地調査を行ない, 次つような結果を得た。

緩傾斜地仙, 最大 $4^{\circ}$ の勾配を的ち, ここて は, stone stripes 様の地形がられる。すな わち, 幅 $50 \mathrm{~cm}$ 前後の高まりと, 幅 2 - 3m D 低志）とか，傾斜方向に，規則的に並んでおり， 斜面下部に虫，高まりの部兮污合一したり， turf-banked benches の形態をとる。高まり は，草およぴ小さな木で一様に覆われている。 これら凹凸地形の横断方向この地下の状態: 罒にみられるように, stone stripes の特丵を 示さない。低まりの部子ての角磁の配置心, polygons の特街を示方 (写真)。

湿地に:は，草占よびわづたの低木で覆われた earth hummock 様つ高去り（径 $50 \mathrm{~cm}$ 内外, 周囲より $10 \mathrm{~cm}$ くら、高、) が点在才る。高 まりの地下構造: ‘, 周囲つ低、所と, 肉眼的に は，何ら変らないことが知られた。

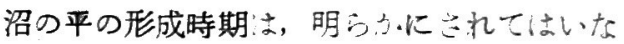
い。従って, 今のところこれら構造土類似の地 形つ生成期について議論うしない。ただ, 当地 のこの地形のすぺてが従来いわれている典型的 な構造土でないことが注目され，またこれに
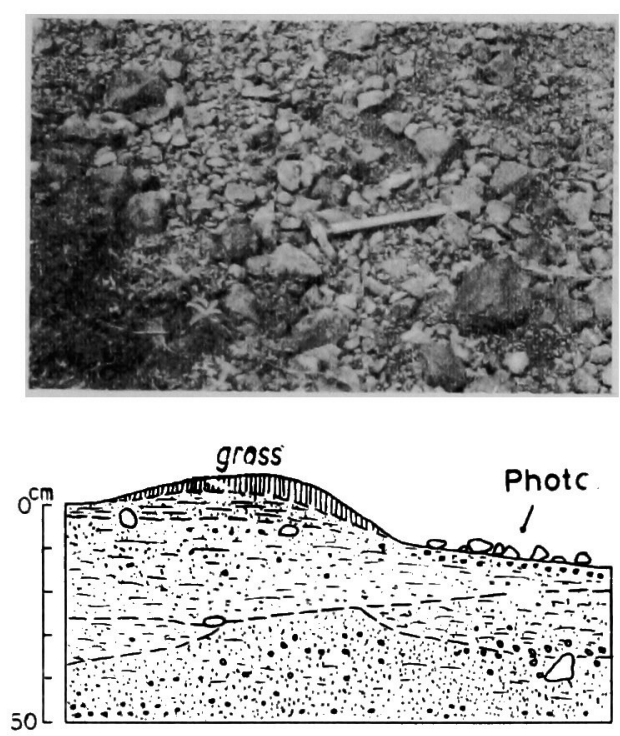

重なった形で構造土が発達していることに興味 がもたれる。この点, 形成期の問題が残されて いるが，T.N. Caine（1963）の報告した例に， 一部似ているといえる.

構造土現象は第四紀の気候変化と関係するだ けでなく，時期をぬいて考えても，その発達位 置が問題であり，C. Troll (1948）が強調する 上うに, その発達は, 風との関係も大きい。気 候景観の 1 つとして興味ある事実とみなし，こ こに報告する次第である。

Caine, T.N. (1903) : The origion of sorted stripes in the Lake District, Northern England Geogr. Annaler $45 \quad 172 \sim 179$

Troll, C. (1948) : Der subnivale oder periglaziale Zyklus der Denudation

Erdkunde $2 \quad 1 \sim 21$

\title{
Patterned Grounds of Numano-taira, Mt. Bantai
}

\section{Tatsuo WAKO, Kunio KANNO, Shoko KOSHIDA, Tei NAKAJIMA, Koya HOSOKAWA, and Osamu MIURA}

In a depression named Numano-taira, $1,380 \mathrm{~m}$ above the sea-level, situated in Mt. Bantai, one can see earth hummocks in its floor, stone-stripe-like linear banks and turf-banked benches on the side slope, $4^{\circ}$ in maximum angle, surrounding its floor.

The structure of linear bank (Fig.) does not show the properties of true stone stripe; the distribution of breccia at the intermediate part between such linear banks (Photo.) exhibits the characteristics of typical polygon. 